\title{
КОНЦЕПТУАЛЬНІ ОСНОВИ УПРАВЛІННЯ РОЗВИТКОМ ПРОФЕСІЙНО-ТЕХНІЧНОГО НАВЧАЛЬНОГО ЗАКЛАДУ
}

Сергеєва Л. М. Концептуальні основи управління розвитком професійнотехнічного навчального закладу.

У статті представлені концептуальні основи управління розвитком професійнотехнічного навчального закладу на основі модернізації змісту управлінської діяльності керівних кадрів профтехосвіти з урахуванням регіонального аспекту, державно-громадського управління, інституційних підходів до управління його розвитком, взаємодії навчальних закладів та регіональних центрів зайнятості, механізмів диверсифікації управління ПТНЗ.

Ключові слова: управління розвитком, критерії ефективності, інституційний розвиток, інституційне освітнє середовище, фактори впливу.

Сергеева Л. Н. Концептуальные основы управления развитием профессионально-технического учебного заведения.

В статье представлены концептуальные основы управления развитием профессионально-технического учебного заведения на основе модернизации содержания управленческой деятельности руководящих кадров профтехобразования с учетом регионального аспекта, государственнообщественного управления ПТУЗ, институциональных подходов к управлению его развитием, взаимодействия учебных заведений и региональных центров занятости, механизмов диверсификации управления ПТУЗ.

Ключевые слова: управление развитием, критерии эффективности, институциональное развитие, институциональная образовательная среда, факторы влияния.

Sergejeva L. N. Conceptual foundations of managing the development of vocational training institutions.

The article describes conceptual foundations of managing the development of vocational training institutions based on modernization of the activity of VET management staff and taking into consideration regional needs, participatory approaches to managing VET training institutions, institutional approaches to managing the development of VET training institutions, cooperation of training institutions and regional employment centers, mechanisms of diversifying VET management.

Key words: managing development, effectiveness criteria, institutional development, institutional educational environment, factors of influence.

Розбудова Української суверенної держави спричинила необхідність зміни системи профтехосвіти, методології і технології організації навчально-виховного процесу професійно-технічного навчального закладу (далі - ПТНЗ), формування системи конкурентоздатних ПТНЗ унаслідок входження їх до ринкових відносин, створення нових типів професійних навчальних закладів, зокрема й недержавних. Основними тенденціями світової професійної освіти XXI століття є ії̈ глобалізація, конкуренція серед фахівців, технологічна й інформаційна революція, глобалізація інформаційного обміну, швидке старіння отриманих знань. В умовах ринкової економіки, інформаційно-технологічного розвитку розширюються функції профтехосвіти, відбувається іï трансформація у професійну освіту і навчання, що 
відповідає світовим тенденціям неперервної освіти - освіти впродовж життя. У всіх цивілізованих країнах здійснюється активний пошук нових моделей розвитку освіти, нетрадиційних підходів до їх упровадження на основі інформаційних та телекомунікаційних технологій [6].

Дослідженню концептуальних основ розвитку навчальних закладів присвячено наукові праці В. Андрущенка, С. Батишева, Г. Дмитренка, Г. Єльникової, В. Олійника, М. Поташника, Н. Ничкало, С. Ніколаєнка, І. Лікарчук, Т. Ломакіної, Л. Оніщук, Н. Островерхова, С. Нікітчиної, О. Новікова, В. Пікельної, В. Радкевич, Л. Сергеєвої, О. Щербак та ін.

Водночас аналіз наукових джерел із теми дослідження засвідчив відсутність праць, присвячених комплексному вивченню проблем управління розвитком ПТНЗ в Україні.

3 огляду на актуальність, теоретичну значущість означеної проблеми метою cmammi є висвітлення концептуальних основ управління розвитком професійнотехнічного навчального закладу.

Сутнісні глобалізаційні зміни потребують нових підходів до управління освітньою галуззю, яка $є$ інтегральною сукупністю освітніх структур, відношень, діяльності та свідомості, що забезпечує відтворення і розвиток інтелектуального потенціалу суспільства. Розроблення концепцій професійно-технічної освіти на різних етапах її існування (Концепція професійної освіти України (2001); Концепція розвитку професійно-технічної (професійної) освіти в Україні (2004); Концепція Державної цільової програми розвитку професійно-технічної освіти на 2011-2015 роки; Концепція розвитку професійно-технічної освіти в Україні на 2010-2020 роки) свідчить про відповідне оцінювання розвитку цієї системи в умовах світових змін $[1 ; 2 ; 3 ; 4]$. В основу цих концепцій було покладено прогностичні ідеї, а в їх змістах враховано стан і прогнози розвитку економіки, ринку праці України, а також об'єктивні потреби оновлення змісту i форм організації навчальновиробничої діяльності, результати наукових досліджень, вітчизняний і зарубіжний досвід професійної підготовки молоді, професійного навчання дорослого населення, навчання протягом усього життя. У концепціях було розкрито положення щодо взаємодії ПТНЗ 3 органами виконавчої влади, науковими установами, роботодавцями, громадськими об'єднаннями, іншими соціальними партнерами. Передбачено впровадження в управлінську діяльність на всіх рівнях новітніх інформативно-управлінських і комп'ютерних технологій.

Аналіз цих документів та сучасної практики управління розвитком ПТНЗ надає нам підстави сформулювати власну систему поглядів на цей процес та визначити шляхи iі реалізації. Ця система поглядів грунтується на виявлених нами cynеречностях, які гальмують цей процес, позначаються на ефективності підготовки конкурентоспроможних робітників, сформованості управлінської компетентності керівників ПТНЗ у сучасних умовах регіонального ринку праці між: соціальним замовленням щодо якісної підготовки кваліфікованих робітників і недостатнім фаховим рівнем іiї здійснення; інтегративним характером вимог, що висуваються до функціонування ПТНЗ, і недостатньою розробленістю теоретико-методичних засад управління його розвитком; традиційним організаційно-методичним інструментарієм здійснення професійної підготовки майбутніх кваліфікованих робітників та необхідністю модернізації цього процесу; необхідністю здійснення цілеспрямованого освітнього менеджменту та браком високоефективних управлінських технологій, спрямованих на ефективний розвиток ПТНЗ.

У контексті вищезазначеного важлива роль відводиться регіональним професійним навчальним закладам, що покликані створити такі моделі управління 
ïx розвитком, які задовольняли б потреби регіонального ринку праці, сприяли б процесам технологізації професійної діяльності педагогічних працівників, адаптації і закріпленню випускників на виробництві та конкурентоспроможності ПТНЗ.

Розробленою нами концепцією управління розвитком ПТНЗ передбачено модернізацію змісту управлінської діяльності керівних кадрів профтехосвіти 3 урахуванням регіонального аспекту державно-громадського управління ПТНЗ, інституційних підходів до управління розвитком ПТНЗ, взаємодії навчальних закладів і регіональних центрів зайнятості, механізмів диверсифікації управління ПТНЗ, технологізації професійної діяльності педагогічних працівників навчального закладу, організаційних механізмів упровадження системи управління конкурентоспроможністю ПТНЗ, інформатизація профтехосвіти як технологічної основи ефективного управління ПТНЗ, сучасних тенденцій формування змісту підвищення кваліфікації керівних та педагогічних кадрів, перспективних напрямів і стратегій управління розвитком ПТНЗ.

Концепцією нашого дослідження передбачено визначення критеріїв ефективності управління розвитком ПТНЗ; організаційного механізму впровадження системи управління конкурентоспроможністю ПТНЗ; технології індикаторно-інструментального оцінювання ефективності діяльності та управління ПТНЗ; інформатизації профтехосвіти як технологічної основи ефективного управління ПТНЗ; технологізації професійної діяльності педагогічних працівників ПТНЗ.

ПТНЗ як інституційне освітнє середовище розбудовується з освітніх ресурсів матеріальних та соціальних цінностей, які належать суб'єктам освітньої діяльності та які вони спрямовують (інвестують) в освітній процес. Смислове значення поняття «інституція»- це «установа, заклад або частина, підрозділ установи, закладу» [5]. Науковці та працівники освіти інституцією вважають установу або заклад і не звертають уваги на те, що це може бути окрема частина або підрозділ установи чи закладу. Така позиція спричиняє втрату інформації й унеможливлює дослідження процесів розвитку освітніх систем на рівнях, нижчих за рівнями акредитації за навчальний заклад або освітню установу.

Передумовою ефективного функціонування ПТНЗ в умовах суспільної турбулентності $\epsilon$ його постійний інституційний розвиток, що базується на професійному розвитку керівних та педагогічних кадрів навчального закладу; організаційному розвитку ПТНЗ як відкритої соціальної системи. Освітні інституції існують у вигляді навчальних закладів, установ освіти, їх підрозділів (частин) чи їх об'єднань. Основні функції освітньої інституції полягають у тому, щоб сформувати стаціонарне, тобто впродовж певного часу незмінне за якісними та кількісними показниками інституційне освітнє середовище та забезпечити його активність у певному напрямі- здійснювати цілеспрямований вплив на учня. Для цього активізуються окремі потенційні можливості, нейтральних за своєю природою матеріальних та соціальних цінностей, які оточують суб'єкти освітньої діяльності або якими ті володіють. Цінностям надається статус освітніх ресурсів, і вони завдяки освітнім технологіям використовуються в освітньому процесі для одержання результатів освітньої діяльності. У подальшому під освітньою інституцією будемо розуміти історично сформований суспільний інструмент створення у просторі освітніх ресурсів інституційного освітнього середовища (далі- IOC), здатного забезпечити одержання тієї чи іншої освітньої послуги (послуг) чи виконання наперед визначеної функції (функцій). 
Інтерес до феномену інституційного освітнього середовища обумовлений його зростаючим значенням як чинника управління розвитком ПТНЗ, який складається 3 тих наукових прогнозів і досліджень, які розглядають IOC як джерело розвитку навчального закладу і як умова якісної професійної освіти. Ідея інституційного освітнього середовища в управлінні ПТНЗ $є$ ключовою. Це така побудова освітнього простору, коли інституційне освітнє середовище розглядається як сукупність змістовних процесів управлінської та професійно-освітньої діяльності суб'єктів. Теоретичне обгрунтування вимог інституційного освітнього середовищного підходу до управління розвитком ПТНЗ здійснюється через діагностування, проектування і перетворення руйнівних можливостей середовища (кризові явища економіки, збільшення попиту на кваліфіковані робітничі кадри, підвищені вимоги роботодавців до якості професійної освіти) на збереження функціонування навчального закладу. Проектування інституційного освітнього середовища представляється нам як аналіз (діагностування) і побудова освітніх ситуацій, в яких вибудовуються якісні зв'язки між суб'єктами середовища (соціальних партнерів, залучення роботодавців у процес підготовки, перепідготовки, підвищенні кваліфікації кадрів, оновлення навчально-матеріальної бази ПТНЗ і змісту професійної освіти, якості надання освітніх послуг, конкурентоспроможності навчального закладу на регіональному ринку праці тощо).

Отже, управління здійснюється через взаємодію і має м'який ненасильницький характер. Спрямовано управління на перетворення середовищ інституційного освітнього простору і представляє діяльність особливого роду. У цьому зв'язку найважливішими завданнями управління $є$ вдосконалення системи та підвищення якості інформаційного забезпечення, визначального своєчасне прийняття якісних управлінських рішень; створення ефективної системи управління якістю освіти, статистики та моніторингу; освоєння управлінськими кадрами сучасних технологій тощо.

Щоб управління мало універсальний характер, наша концепція управління розвитком ПТНЗ побудована в логіці еволюції науки управління, зіставленні провідних методологічних підходів: системного, функціонально-структурного, ситуативного, синергетичного, середовищного. Управлінські дії передбачають перманентну зміну (перетворення), деяку плинність і перехід з однієї якості ситуації в ситуацію іншої якості. Це визначає, що інституційне освітнє середовище, будучи засобом та умовою розвитку, визначає характер управлінських дій. Інтеграція позитивних можливостей управлінських ситуацій щодо перетворення інституційного освітнього середовища зумовлює створення професійно-освітнього простору ПТНЗ у регіоні. Поняття «регіональний освітній простір» можна розглядати у двох площинах: як середовище, територію, в межах якої діють єдині, узгоджені правила інноваційної діяльності, і як цілісну систему, результатом функціонування якої є новітні ідеї та оригінальні технології.

Механізм формування управлінського освітнього простору ПТНЗ складається 3 двох елементів: статичного (визначення етапів організаційно-управлінської діяльності) та динамічного (моделювання організаційної структури управління розвитком ПТНЗ). Складниками такої системи можуть бути такі компоненти: інфраструктура, кадровий потенціал, управлінська культура та моніторинг управлінської діяльності. Усі компоненти системи взаємопов'язані, взаємозумовлені. Зазначені складники тільки в єдності творять цілісну систему, чітке функціонування якої здатне породжувати нову якість у вигляді нових ідей та досвіду. Водночас 
важливою умовою їх реалізації $\epsilon$ створення механізму функціонування цілісної системоутворювальної діяльності, яка забезпечить якість інноваційної продукції.

Отже, розвиток полягає у змінах, у різному темпі і з різною інтенсивністю, у більш оптимальному співвідношенні, сукупності головних та змістовних, а також другорядних характеристик стану систем різного роду, які взаємодіють у різному плані, по-різному адаптуються один до одного. При цьому одні 3 систем більш активні й агресивні, але не в змозі існувати одна без іншої. Практика формування інституційного освітнього середовища визначається такими чинниками: раптовістю, актуальністю, невизначеністю, новизною, нестандартністю, екстремальністю професійно-управлінської праці.

Виходячи 3 перерахованих чинників, можна виокремити провідні компоненти у змісті управління розвитком ПТНЗ: мотиваційний, пізнавальний, функціональнодіяльний. Для педагогічної теорії і практики важливо віднайти такий механізм реформування (перетворення, змінювання, модернізації, оновлення) освітніх систем, який одночасно $є$ i їх природним розвитком (саморозвитком), і забезпечує досягнення наперед визначених цілей обраним способом протягом визначеного періоду. Роль теорії і практики освітнього менеджменту в сучасних умовах модернізації управління розвитком ПТНЗ перетворюється на рушійну силу освітнього процесу, стає чинником якості вітчизняної ПТО в період її входження до єдиного європейського та світового простору.

Важливо, щоб знання про механізми реформування профтехосвіти були представлені і як цілісна теорія, i як ефективна технологія, що дозволить практичним працівникам забезпечувати розвиток інституційних освітніх систем у конкретних умовах їх функціонування. Теорія модернізації управління розвитком ПТНЗ передбачає запровадження інноваційних технологій управління якістю профтехосвіти: розроблення та впровадження державних стандартів ПТО 3 професій широких кваліфікацій; оновлення та затвердження оптимального переліку професій з підготовки кваліфікованих робітників (скорочення їх кількості на основі інтеграції); оптимізацію мережі ПТНЗ різних типів, професійних спрямувань і форм власності $з$ урахуванням демографічних прогнозів, регіональної специфіки та потреб ринку праці; розширенні їх автономії, створення навчально-виробничих комплексів; удосконалення механізму формування державного замовлення на підготовку робітничих кадрів відповідно до реальних потреб економіки, регіональних ринків праці, запитів суспільства; удосконалення системи підготовки, перепідготовки і підвищення кваліфікації педагогічних працівників ПТО та базі вищих навчальних закладів та профільних ПТНЗ.

Узагальнюючи викладене, ми вважаємо, що розвиток ПТНЗ може бути забезпечений на основі:

- посилення гуманізації всіх відношень між суб'єктами навчально-виховного і навчально-виробничого процесів на всіх рівнях профтехосвіти знизу догори;

- перетворення формального керівництва та управління безвідповідального на наукове, високопрофесійне;

- створення організаційно-психологічних умов задля об'єднання педагогів і учнів, для їх кооперації в педагогічній галузі, для запобігання розриву в ланцюзі передавання знань, умінь та навичок у професійній освіті та навчанні;

- створення відповідного освітнього середовища;

- створення організаційно-педагогічних умов залучення роботодавців до управління розвитком ПТНЗ; 
- розвитку процесу диверсифікації профтехосвіти у контексті інституційного розвитку ПТНЗ;

- професійного розвитку і саморозвитку педагогічного колективу ПТНЗ;

- інформатизації профтехосвіти як технологічної основи ефективного управління ПТНЗ;

- ефективності критеріального підходу до діагностування професійної діяльності педагога ПТНЗ;

- взаємодії ПТНЗ та регіональних центрів зайнятості.

Характеристика цих підстав надала змогу визначити перспективні напрями i стратегії управління розвитком ПТНЗ (маркетинг у профтехосвіті; бенчмаркінг як неперервний процес покращення технологій надання освітніх послуг; упровадження механізмів інформаційної логістики в освітньому менеджменті ПТНЗ; основи освітнього реінжинірингу і мерчендайзингу як модернізуючий механізм управління організаційними освітніми змінами; технології створення позитивного іміджу навчального закладу).

На нашу думку, ефективність технології управління розвитком ПТНЗ має здійснюватися на засадах інноваційних стратегій відповідно до принципів розвитку (демократичності, гуманістичності, фундаменталізації, цілісності, єдності та наступності, суб'єкт-суб'єктної взаємодії, технологізації, інтеграції 3 наукою та виробництвом, взаємозв'язку 3 освітою інших країн, гнучкості та прогностичності управлінської системи, безперервності й різноманітності, багаторівневості, диверсифікації, децентралізація, адаптивності, інтегрованості, відтворення кадрових ресурсів та їх модернізація, професійної рефлексії керівних кадрів тощо) задля посилення ролі та взаємодії всіх суб'єктів освітньої політики, у якій особистість, суспільство й держава стають рівноправними суб'єктами і партнерами розвитку моделі державногромадського управління, створення сучасних систем освітніх проектів та моніторингу.

Це передбачає діяльність організаційного механізму впровадження системи управління конкурентоспроможністю ПТНЗ; бізнес-планування як процес розвитку ПТНЗ; проектування навчальних програм профтехосвіти на основі потреб галузі й громади; взаємодію ПТНЗ і роботодавців у підготовці робітничих кадрів для ринку праці; впровадження системи попереднього оцінювання та зворотного зв'язку і аналізу трудової успішності випускників ПТНЗ; впровадження диверсифікаційної адаптивності ПТНЗ до мінливих умов регіонального ринку праці; взаємодію ПТНЗ та регіональних центрів зайнятості; впровадження технологій маркетингових комунікацій ПТНЗ; технологізації професійної діяльності, професійного розвитку і саморозвитку педагогічних працівників ПТНЗ; інформатизації профтехосвіти як технологічної основи ефективного управління ПТНЗ (рис. 1).

Розгляд понятійного апарату дослідження, узагальнення поглядів науковців щодо проблеми управління розвитком навчального закладу, виокремлення напрямів, стратегій та організаційних механізмів управління, конкурентоспроможністю ПТНЗ на основі сучасних потреб галузі, регіонального ринку праці та громади дозволило обгрунтувати та визначити сутність процесу управління розвитком ПТНЗ. Цей процес ми розуміємо як складну інтегративну діяльність педагогічного колективу ПТНЗ, що спрямована на якісне оновлення навчально-виробничого процесу i визначається задоволеністю споживача професійно-освітніх послуг та цілісним професійним іміджем навчального закладу.

Об'єктом змін можуть бути: зміст професійної освіти, ринок праці, соціальне партнерство, ринок освітніх послуг, що потребує інноваційних управлінських дій: 
бізнес-планування, проектування навчальних програм на основі потреб галузі й громади, аналізу фахової успішності випускників та співпраці з регіональними центрами зайнятості, модернізації матеріально-технічної бази; здійснення ефективного фінансово-економічного забезпечення навчального закладу шляхом удосконалення якості освіти на основі розвитку партнерської співпраці 3 замовниками робітничих кадрів, диверсифікація джерел фінансування; усуспільнення ПТНЗ на основі системи управління конкурентоспроможністю та маркетингового інструментарію управління розвитком ПТНЗ.

Аналіз існуючих концепцій професійно-технічної освіти на різних їі етапах існування (2001-2020 pp.), стану і прогнозів розвитку економіки та ринку праці України надав змогу сформулювати власну систему поглядів на процес управління розвитком ПТНЗ та визначити чинники впливу на ефективність управління розвитком ПТНЗ.

Здійснене теоретичне обгрунтування вимог інституційного освітнього середовищного підходу до управління розвитком ПТНЗ, що здійснюється шляхом діагностування, проектування і перетворення руйнівних можливостей середовища, підтвердило теоретичну й експериментальну апробацію розробленої концепції, у якій визначаються, що механізм формування управлінського освітнього простору ПТНЗ складається $з$ елементів.

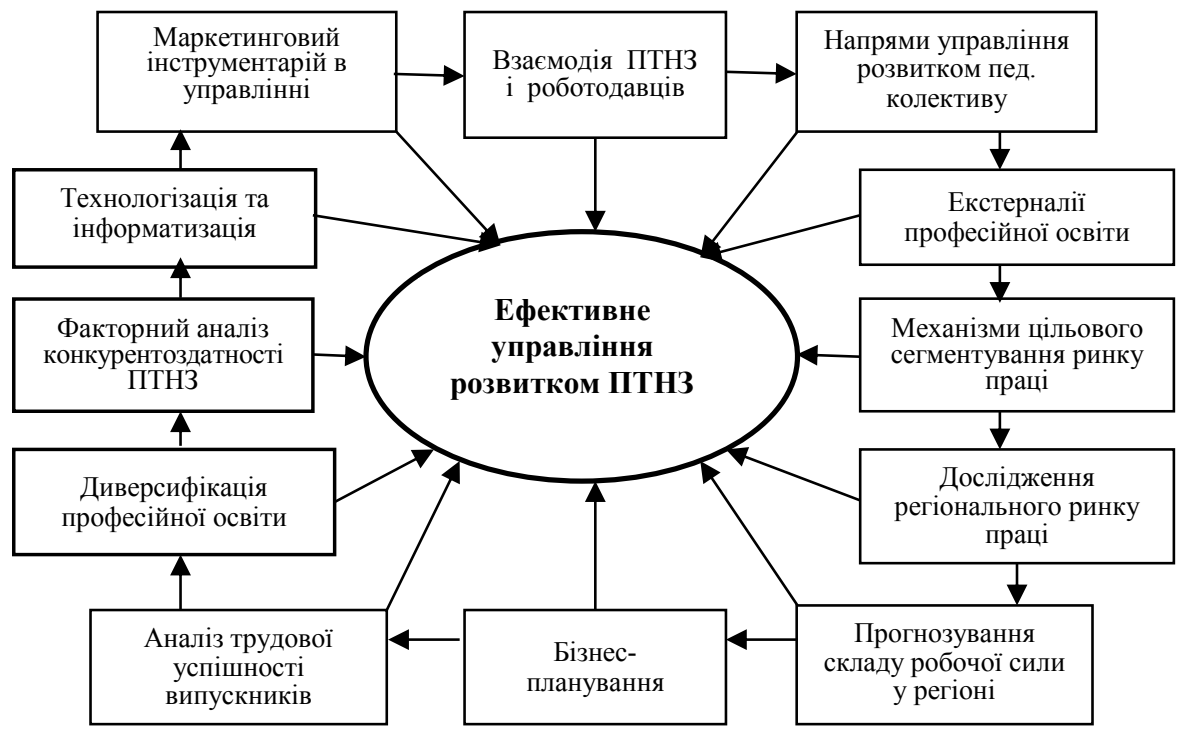

Рис. 1. Чинники впливу на ефективність управління розвитком ПТНЗ

\section{Література}

1. Концепція професійної освіти України. Постанова Міністерства народної освіти УРСР, Міністерства праці УРСР, Академії наук УРСР від 24 липня 1991 р. № 7/52/59. - 14 с. 2. Концепція розвитку професійно-технічної (професійної) освіти в України // Освіта України. - Від 20 липня 2004 р. - № 56-57. - С. 3-5. 3. Концепція Державної цільової програми розвитку професійно-технічної освіти на 2011-2015 роки, Розпорядження Кабінету Міністрів України від 27 серпня 
2010 p. № 1723-p [Електронний ресурс]. - Режим доступу: http://guonkh.gov.ua/ content/documents/12/1105/Attaches/ Kontseptsiya.doc 4. Концепція розвитку професійно-технічної освіти в Україні на 2010-2020 роки // Інформаційний збірник Міністерства освіти і науки України : офіц. вид. МОН України. - 2010. - № 17/18. С. 13-19. 5. Мещанінов О. П. Сучасні моделі розвитку університетської освіти в Україні: [монографія]/ О. П. Мещанінов. - Миколаїв: Вид-во МДГУ ім. Петра Могили, 2005. - 460 с. 6. Ничкало Н. Г. Развитие человеческого капитала стратегическое задание профессионального образования / Н. Г. Ничкало // Модернизация профессионального образования : теория, опыт, проблемы / сост. Т. Ю. Ломакина; под. науч. ред. Т. Ю. Ломакиной; Федеральное государственное научное учреждение «Институт теории и истории педагогики» РАО / [монография].- М.: ФГНУ ИТИП РАО, 2012. - 318 с. - С. 201-220. 7. Сергесва Л. М. Управління розвитком професійно-технічного навчального закладу: теорія і методика : [монографія]/ Л. М. Сергеєва; за наук. ред. В. В. Олійника. - К.; Херсон : Айлант, 2013. - 452 с.

\section{ПРОЕКТУВАННЯ ПЕДАГОГІЧНОЇ СИСТЕМИ ПІДГОТОВКИ МАГІСТРІВ-ІСТОРИКІВ}

Третяк О.С. Проектування педагогічної системи підготовки магістрівісториків.

Досліджується проблема проектування педагогічної системи підготовки магістрів-істориків до наукової діяльності та тлі розширення змісту методології індивідуального навчання в університеті.

Ключові слова: проектування педагогічної системи, контекстно-орієнтоване навчання магістрів, індивідуальні технології в навчанні магістрів-істориків.

Третяк Е. С. Проектирование педагогической системы подготовки магистровисториков.

Исследуется проблема проектирования педагогической системы подготовки магистров-историков к научной деятельности на фоне расширения содержания методологии индивидуального обучения в университете.

Ключевые слова: проектирование педагогической системы, контекстно ориентированное обучение магистров, индивидуальные технологии в обучении магистров-историков.

Tretjak H. S. Planning of pedagogical training system for masters of history.

The problem of planning of Pedagogical training system for Masters of History for their scientific activities on the basis of methodology improving for personal training in the University is researched.

Key words: planning of pedagogical system, context oriented training of Masters, individual technologies in Masters of History training.

Підготовка педагогів-істориків у магістратурі передбачає випускати високоосвічених фахівців, здатних динамічно змінюватись в умовах сучасної школи і готових до науково-дослідної діяльності, яка потребує вмінь та навичок до аналізу, порівняння та узагальнення, синтезу, моделювання та проектування, 